\title{
BANGLADESHI MONETARY POLICY TRANSMISSION MECHANISM: ASYMMETRIC RESPONSES, INFLATION, AND POLICY TIME LAGS
}

\author{
Chu V. Nguyen ${ }^{1}$, Anisul M. Islam ${ }^{2}$ and Muhammad Mahboob Ali 3
}

\begin{abstract}
This study empirically documented that the Bangladeshi inflation converts to its long-run threshold faster when it is above than when it is below the endogenously determined threshold. Furthermore, the estimation results reveal the unidirectional Granger causality from the real GDP growth rate to the countercyclical monetary policy, i.e., the real GDP growth rate is weakly exogenous from the Bangladeshi countercyclical monetary policy actions. These findings indicate that even though the Bangladeshi Central Bank uses its monetary policy to manage the macro economy, money and hence monetary policy seem not to matter in the short run.
\end{abstract}

Keywords: Asymmetry; Quantity Theory's Based Inflation; Money Supply; Real GDP; Impact Lag; Bangladesh.

JEL Classification: C22; G21.

\section{INTRODUCTION}

The connection between increase in money supply and inflation has been recognized by researchers for centuries. As pointed out by Hubbard and O'Brien (2010, p. 846), as early as the sixteenth century, the Spaniards conquered Mexico and Peru and shipped a large quantity of gold and silver back to Spain. These precious metals were minted into coins and spent across Europe to further the political ambitions of Spanish kings, causing steady increases in prices in Europe. This phenomenon was again observed when gold and silver were shipped from the Americas to Europe.

\footnotetext{
1 University of Houston-Downtown - Email: nguyenchu@uhd.edu.

2 University of Houston-Downtown - Email: islama@uhd.edu.

3 Presidency University - Email: pipulbd@gmail.com.
} 
Irving Fisher (1911) formalized the above connection by his famous algebraic identity, known as the equation of exchange. Milton Friedman (1956) in his centennial study redefined the variables of Fisher's identity to formulate the quantity theory of money. Under the assumption of constant velocity of money, the quantity theory of money equation is then algebraically manipulated to express the inflation rate over time as the spread between the two related time series data of rates of growth of money supply and the real GDP of an economy.

Additionally, since the late 1930s, Keynesian fiscal policy has played a critical role in macroeconomic management in market economies. Beginning in the 1960s, changes in international economic conditions resulted in persistently large government budget deficits in economies around the world. As articulated by Mishkin (1995, p. 3), partly because of concern over persistent budget shortfalls including large public debts, and partly because of doubt about the political system's ability to utilize the fiscal policy instrument in a timely and effective manner to achieve the desirable stabilization outcome, fiscal policy has lost its luster. Consequently, the stabilization of output and inflation has been delegated largely to monetary policy.

Recently, Bernanke and Gertler (1995, p. 27) pointed out that monetary policy, at least in the short run, can affect the real economy. Recent empirical research (Romer and Romer, 1990; Bernanke and Blinder, 1992; Christiano, Eichenbaum, and Evans, 1994) confirmed earlier findings by Friedman and Schwartz (1963) that monetary policy actions affected the real output of the economy for the succeeding two years or more. Certainly, monetary policy is a powerful tool; however, Mishkin $(1995$, p. 4) argued that this instrument has unintended consequences. Therefore, to conduct monetary policy successfully, the monetary authorities must have accurate knowledge as to the timing and the effect of their policy actions on the economy. This in turn requires the policymakers to understand the mechanism through which monetary policy affects the economy, which is often known as the monetary transmission mechanism, dubbed by economists as the so-called "black box".

Clearly, monetary policy becomes more and more important as an instrument for macroeconomic policy-making and macroeconomic management. As pointed out by Bernanke and Gertler $(1995$, p. 27), the same research that has established that changes in monetary policy are eventually followed by changes in real output is largely silent about what happens in the interim. To address this void, the fall 1995 issue of the Journal of Economic Perspectives arranged a symposium on the monetary transmission mechanism. At this symposium, major papers were presented by prominent economists such as Frederic S. Mishkin, John B. Taylor, Ben S. Bernanke and Mark Gertler, Allan 
H. Meltzer, and Maurice Obstfeld and Kenneth Rogoff. In summarizing the papers presented at the symposium, Mishkin (1995, pp. 4-9) articulated that these authors identified several important channels through which monetary policy actions are transmitted to real economic activities: the interest rate channel, the exchange rate channel, other asset price effects, and the credit channel.

From another perspective, the asymmetric behavior in the context of the spread between two related times series data in financial markets has been studied extensively and documented in the literature. Arak et al. (1983), Goldberger (1984), Forbes and Mayne (1989), Levine and Loeb (1989), Mester and Saunders, (1995), Dueker (2000), and Tkacz (2001) report asymmetries in the U.S. prime lending rate. Thompson (2006) confirms the asymmetries in the U.S. prime lending-deposit rate spread. Cook and Hahn (1989), Moazzami (1999), and Sarno and Thornton (2003) find asymmetries in U.S. Treasury securities. Frost and Bowden (1999) and Scholnick (1999) report asymmetries in mortgage rates in New Zealand and Canada. Heffernan (1997) and Hofmann and Mizen (2004) indicate asymmetric behavior of retail rates in the United Kingdom. Nguyen and Islam (2010) documented the asymmetric cointegration relationship between lending and deposit rate spread in Thailand. Similarly, Hannan and Berger (1991), Neumark and Sharpe (1992), and Diebold and Sharpe (1992) examined asymmetric relationships for various deposit and lending rates.

The most important uncertain issues faced by monetary policy makers are how the policy actions affect the target variables, the unintended consequences, and the time lags. These issues have been theoretically articulated, but their empirical magnitudes vary from one economy to another. Therefore, for a particular economy, these specific quantities must be found empirically. It is generally accepted that the time lags of the countercyclical monetary policy actions are longer than those of the fiscal policy in the developed countries. To the best of our knowledge, the Bangladeshi transmission mechanism of the countercyclical monetary policy has not been investigated by any prior empirical study.

In light of the aforementioned considerations, this study utilizes recently developed methodologies in time series analysis to investigate the following questions. First, are asymmetries present in the Quantity Theory's based inflation rates in Bangladesh? Second, if the asymmetries exist, how does the Bangladeshi Central Bank, through changing the quantity of money supply, respond to such asymmetries? Third, and perhaps more interestingly, the empirical results may reveal the nature of causality between changes in the money supply and changes in real GDP as well as the time lags of this 
causality of the Bangladeshi economy. The remainder of the paper is organized as follows: The next section summarizes the characteristics of the Bangladeshi economy and the banking sector; the following section describes the data used in this study; the section after that summarizes the analytical framework and methodological issues of this study; the following section reports the empirical results followed by the empirical findings and possible policy implications; the final section provides the concluding remarks.

\section{THE BANGLADESHI ECONOMY}

From the independence of the country on December $16^{\text {th }}, 1971$ to December 1989, the Bangladeshi financial sector was controlled under the strict directives of the government and Bangladesh Bank - the Central Bank of Bangladesh. Since 1974, the bank rate policy has often used to support Bangladesh Bank's administered interest rate policy. In the early years of Bangladesh, bank rate, reserve ratios and moral suasion (known as open mouth persuasion) were important instruments to control money supply. With the introduction of the Financial Sector Reform Program in 1990, the Bangladesh Bank almost closed both the refinance and rediscount windows with a view to developing an inter-bank market.

The last decade witnessed some major policy shift as the Bangladesh Bank introduced repurchase agreement in July 2002 and Reverse Repo in April 2003 and reintroduced Bangladesh Bank Bill in 2006. These were introduced as indirect monetary policy tools for day-to-day liquidity management in response to temporary and unexpected disturbances in the supply of and demand for money. The initiatives of the Central Bank to face the situation through reform measures since 1990 no doubt have improved the capital adequacy, governance, regulation and supervision, legal and payment systems in the economy. The banking sector has developed to become the dominant financial intermediary in the Bangladeshi financial system due to the underdeveloped money and capital markets, limited availability of financial instruments, and lack of confidence in the financial system as a whole. The Bangladesh Bank still cannot determine monetary policy independently. Government is still playing an important role in the financial sector as major borrowers from the banking system. Additionally, the government has directly interfered in the monetary policy management of the Bangladesh Bank. According to a report published in Daily Star (9 ${ }^{\text {th }}$ June, 2012) the government's target for borrowing from banks was set at around Tk 19,000 crore for the fiscal year 2011-12, but within the first half of the year 
borrowing exceeded Tk 21,000 crore, leaving the private sector entrepreneurs in a liquidity crisis. Recent scandals of the banking sector including Hallmark scam creates panic among the stakeholders of the banking sector but still no effective corrective measures have been taken.

Interventions in the financial sector should not be unexpected in a poor developing country such as Bangladesh. As the consequences of extensive government interventions in the form of licenses and permits as well as directives, the ownerships of private institutions and controls of public institutions are given to a few individuals who are well-connected politically, resulting in inefficient banking sector. Further, tussle between ministry of finance and Bangladesh bank's control over nationalized commercial banks create an environment of mismanagement of the banking sector. Khatun (2012, p. 12) observes that the recent financial scam is an eye-opening incident for all associated with banking sector as well as the policy makers exposing the inherent weaknesses of the banking sector of the country. In view of the recent irregularities, appropriate measures ought to be undertaken in the short to the medium term towards improved performance of the sector. This should range from proper investigation and punishment of involved persons to improvement of the monitoring and governance of the state owned commercial banks. Interest rate on lending and deposit both are high and interest rate spread is quite high. According to World Bank (2012), interest rate spread is $6.7 \%, 6.4 \%$, and $5.9 \%$ in the year 2008, 2009, and 2010 respectively.

The monopolistic and oligopolistic market structures coupled with the political connections of a few powerful individuals and corruptions would invariantly lead to cartels and rate fixings (Nguyen and Islam 2010). These factors would hinder the effectiveness of the national economic policy actions and result in asymmetric adjustment in product and service pricings, and an unfair distribution of national income in favor of the few. Naturally, these above phenomena would likely result in higher lending rates, lower deposit rates and hence higher lending-deposit rate spread as well as predatory pricing behavior in the banking industry (Nguyen and Islam 2010 and Mujeri and Islam 2008). Ahmad (2012) observes that controlling inflation has been a major challenge in the first two years of the Sixth Plan. However since the second half of FY12 to tighten domestic credit and money supply has yielded positive results ${ }^{4}$.

4 http://www.pri-bd.org/index.php?option=com_content\&view=article\&id=368:thechallenge-of-controlling-inflation\&catid=47:bangladesh-economy\&Itemid=59). 


\section{THE DATA}

One of the challenges in empirical studies of emerging economies is the lack of desirable data. This study uses quarterly data on the Bangladeshi narrowly defined money supply $\mathrm{M}_{1}$ and the real GDP over the period 1973:Q1 to 2009:Q4 where the data is available. Additionally, only annual GDP data is available, and this study uses an interpolation method to convert annual to quarterly data using the well-known linear interpolation method. Given the long-time period of data involved, the biases that may have been created by the interpolation method is expected to be minor; it is expected that the possible positive bias would be cancelled out by the possible negative bias with the result that the long-run impacts would remain minimal.

\section{Figure 1}

\section{Changes in Bangladeshi Money Supply M1 and Real GDP Growth Rates}

Quarterly Data: 1973-Q2 to 2009-Q4

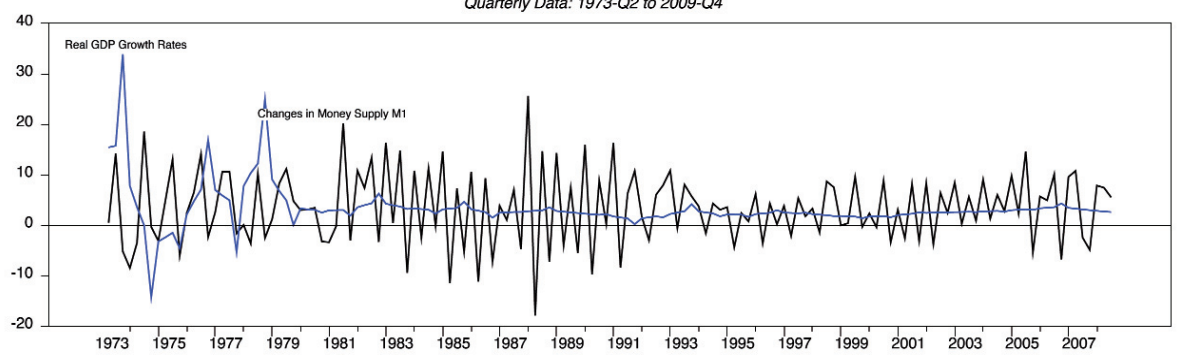

Figure 1 displays the behavior of the respective percentage changes in the Bangladeshi quarterly money supply GDP, and the quantity theory defined inflation which is equal to the sum of the percentage changes in money supply $\mathrm{M}_{1}$ and the change its velocity minus the percentage in the real GDP. The mean percentage change in money supply during this period is 3.49 percent, and ranges from -17.87 to 25.67 , with a standard error being 7.19 . The mean percentage change in real GDP over the same period is 3.37 percent, and ranges from -14.20 to 33.91 , with a standard error being 4.48 . The mean quantity theory defined inflation rate during this period is 0.50 percent, and ranges from -0.20 to 4.67 , with a standard error being 0.77 . 


\section{ANALYTICAL FRAMEWORK AND METHODOLOGICAL ISSUES}

\subsection{Analytical Framework}

The ongoing debate between monetarist and Keynesian economics is complicated because it means different things to different people. However, most people would agree that the main position of the monetarists is that "money matters". In the aggregate-demand-aggregate-supply (AD-AS) framework, an increase in the money supply shifts the AD to the right, leading to an increase in both aggregate output and price level. As aforementioned, Irving Fisher (1911) introduced the velocity of money and quantified the connection by his famous algebraic identity, known as the equation of exchange, equation (1).

$$
M_{t} \cdot V_{t}=P_{t} \cdot T_{t}
$$

where $M_{t}$ is the stock of money, $V_{t}$ is the velocity of money, $\mathrm{P}_{t}$ is the overall price level, and $T_{t}$ is the transaction volume in the period $t$.

Milton Friedman (1956) articulated that the velocity of money is relatively constant and denoted by $\bar{V}_{t}$, to restate the Fisher identity, which has become known as the quantity theory of money as expressed by equation (2).

$$
M_{t} \cdot \bar{V}_{t}=P_{t} \cdot y_{t}
$$

Where $y_{t}$ is real GDP at time t. Let $\partial M_{t}$ denote "the growth rate of" a variable, i.e., $\partial M_{t}$ is the growth rate of money supply $M_{t}$. The quantity theory of money equation can then be algebraically manipulated to express as:

$$
\partial y_{t}=\partial \bar{V}_{t}+\partial M_{t}+\left(-\partial P_{t}\right)
$$

As aforementioned, $P_{t}$ is the overall price level, therefore, $\partial P_{t}$ is referred to as the Quantity Theory's based inflation rate in this study; henceforth referred to as the inflation rate. $\partial y_{t}$ is the growth rate of real GDP. $\partial \bar{V}_{t}$ is the change of velocity of money. From monetarist perspectives, the velocity of money is determined largely by institutional arrangements specific to the economy, such as how often people are paid, population characteristics, payment technologies, and so on; therefore, velocity of money $\left(\bar{V}_{t}\right)$ is essentially constant, hence $\partial \bar{V}_{t}$ is zero.

From the monetarists' perspective, inflation rate is the spread between the growth rate of money supply and the growth rate of real GDP. Given the aforementioned, equation (3) can be viewed as a regression model that relates the two time series - the growth rate of real GDP to the growth rate of 
money supply - with $\partial P_{t}$ being the residual of the model. For proper interpretation of the empirical results, it is important to note the negative sign preceding the $\partial P_{t}$ in equation (3). Given the current level of real GDP and the velocity of money, an expansionary monetary policy; i.e., an increase in money supply would push the $\left(-\partial P_{t}\right)$ below its threshold algebraically; while a contractionary countercyclical policy would push the $\left(-\partial P_{t}\right)$ above its threshold algebraically.

\section{METHODOLOGICAL ISSUES}

Econometrically, to empirically investigate the nature of the countercyclical monetary policy transmission mechanism, using the above analytical framework, the changes in money supply and the real GDP growth rates series must be tested for stationarity and/or cointegration. The Dickey-Fuller standard unit root tests and their extensions assume that the adjustment process is symmetric. If the adjustment process is asymmetric, then the implicitly assumed restrictive symmetric adjustment is indicative of model misspecification. Fortunately, recent developments in advanced statistical methodology, specifically the threshold autoregressive (TAR) and the threshold autoregressive vector error-correction (TAR-VEC) models, developed by Enders-Siklos (2001), resolved the misspecification involving the asymmetric adjustments. First, the TAR model provides a procedure to test for the stationarity and cointegration of the changes in money supply and the real GDP growth rates series, allowing asymmetric adjustments. Second, the TAR-VEC model may then be used to empirically investigate how the countercyclical monetary policy affects the output and other attendant issues in the short and long runs.

Technically, Enders and Siklos (2001) extended the popular two-step symmetric Engle-Granger (1987) methodology to test for long-run relationships between two time series allowing for asymmetry. As demonstrated by Enders and Siklos (2001), the first step in the procedure is to estimate the following long-run relationship between the real GDP growth rates and the changes in money supply $\mathrm{M}_{1}$ as specified in equation (3) using ordinary least squares. The saved negative residuals $\left(-\partial P_{t}\right)$, denoted by $\hat{\varepsilon}_{t}$, are then used to estimate the following TAR model:

$$
\Delta \hat{\varepsilon}_{t}=I_{t} \rho_{1} \hat{\varepsilon}_{t-1}+\left(1-I_{t}\right) \rho_{2} \hat{\varepsilon}_{t-1}+\sum_{i=1}^{p} \alpha_{t} \Delta \hat{\varepsilon}_{t-p}+\hat{u}_{t}
$$


where $\hat{u}_{t} \sim$ i.i.d. $\left(0, \sigma^{2}\right)$ and the lagged values of $\Delta \hat{\varepsilon}_{t}$ are meant to yield uncorrelated residuals. It is also noted that $\hat{\varepsilon}_{t}$ is the changes in money supply $\partial M_{t}$ and the spread between the real GDP growth rates and henceforth the inflation rates as defined by the quantity theory. As defined by Enders and Granger (1998), the Heaviside indicator function for the model is given as:

$$
I_{t}= \begin{cases}1 & \text { if } \hat{\varepsilon}_{t-1} \geq \tau \\ 0 & \text { if } \hat{\varepsilon}_{t-1}<\tau\end{cases}
$$

The threshold value, $\tau$, is endogenously determined using Chan's (1993) procedure, which obtains $\tau$ by minimizing the sum of squared residuals after sorting the estimated residuals in ascending order, and eliminating 15 percent of the largest and smallest values. The elimination of the largest and smallest values is to assure that the $\hat{\varepsilon}_{t}$ series crosses through the threshold in the sample period. As pointed out by Thompson (2006, p. 326), if the TAR model rejects the null hypothesis of symmetric adjustment, the sample mean is a biased estimate of the threshold. Chan's (1993) method yields the consistent estimate of the threshold. In this model's specification, the null hypothesis that the Bangladeshi inflation rate contains a unit root can be expressed as $\rho_{1}=\rho_{2}=0$, while the hypothesis that the inflation rate is stationary with symmetric adjustments can be stated as $\rho_{1}=\rho_{2}$.

The threshold autoregressive model allows the degree of autoregressive decay to depend on the state of the quantity theory's defined inflation rate of Bangladesh in the previous period (i.e., "deepness" of cycles). The empirical result reveals if the inflation rate tends to revert to the long-run position faster when it is above or below the threshold. Therefore, the TAR model indicates whether troughs or peaks persist more when shocks push the Bangladeshi inflation rate out of its long-run path.

\section{EMPIRICAL RESULTS}

\subsection{Unit Root Test}

The estimation results of the TAR model are summarized in Table 1. An analysis of the overall empirical results indicates that the estimation results are devoid of serial correlation and have good predicting power, as evidenced by the Ljung-Box statistics and the overall F-statistics, respectively. With the calculated statistic $\Phi_{\mu}=25.7642$, the null hypothesis of a unit root $\left(\rho_{1}=\rho_{2}=0\right)$ is rejected at the 1 percent significance level (i.e., the Bangladeshi 
inflation rate is stationary). As to the speed of adjustment, based on the partial test statistic $\mathrm{F}=5.5055$, the null hypothesis of symmetry, $\rho_{1}=\rho_{2}$, is rejected at 5 percent significance level. Thus, the empirical results indicate that adjustments around the long-run threshold value of the Bangladeshi inflation rate are asymmetric. In fact, the point estimates suggest that inflation tends to decay at the rate of $\left|\rho_{1}\right|=0.8798$ for $\Delta \hat{\varepsilon}_{t-1}$ above the threshold, $\tau=1.89102$, and at the rate of $\left|\rho_{2}\right|=0.4823$ for $\Delta \hat{\varepsilon}_{t-1}$ below the threshold. Also, both $\rho_{1}$ and $\rho_{2}$ are statistically significant at 1 percent level. Furthermore, the estimates of $\rho_{1}$ and $\rho_{2}$ satisfy the stationary (convergence) conditions ${ }^{5}$. With regard to the stationarity of the inflation series, Ewing et al. (2006, p. 14) pointed out that this simple finding is consistent with the two underlying series that comprise the spread (the Bangladeshi growth rates of money supply $\partial M_{t}$ and real GDP) being cointegrated in the conventional, linear combination sense.

\section{Table 1: Unit Root and Tests of Asymmetry, Bangladeshi Quarterly Data, 1973: $Q 2$ to 2009: $Q 4$}

\begin{tabular}{|c|c|c|c|c|c|}
\hline$\rho_{1}$ & $\rho_{2}$ & $\tau$ & $H_{0}: \rho_{1}=\rho_{2}=0$ & $H_{0}: \rho_{1}=\rho_{2}$ & aic \\
\hline$-0.8798^{*}$ & $-0.4823^{*}$ & 1.89102 & $\Phi_{\mu}=25.7642^{*}$ & $\mathrm{~F}=5.5055^{* *}$ & 1309.6554 \\
\hline \multicolumn{2}{|c|}{$Q_{L B(2)}=1.6770[0.4323]$} & $\ln L=-367.5641$ & $F_{(4,135)}=18.1552^{*}$ & \\
\multicolumn{2}{|c|}{$3.160[0.206][0.118]$} & & & \\
\hline
\end{tabular}

Notes: The null hypothesis of a unit root, $H_{0}: \rho_{1}=\rho_{2}=0$, uses the critical values from Enders and Siklos (2001, p. 170, Table 1, for four lagged changes and $n=100)$. "** and "**" indicate 1 and 5 percent levels of significance, respectively. The null hypothesis of symmetry, $H_{0}: \rho_{1}=\rho_{2}$, uses the standard F distribution. $\tau$ is the threshold value determined via the Chan (1993) method. $Q_{L B}$ (2) denotes the Ljung-Box $Q$-statistic with 2 lags.

With regard to the adjustment process, given $\left|\rho_{1}\right|>\left|\rho_{2}\right|$, the estimation results suggest that the Bangladeshi inflation coverts to its long-run threshold faster when monetary policy action or economic shock pushes it below then when is above the long-run threshold. As aforementioned the negative sign preceding the term $\partial P_{t}$ in equation (3), seems to suggest that the Bangladeshi inflation rate responds more quickly to contractionary countercyclical monetary policy actions than it does to expansionary policy.

5 As shown by Petrucelli and Woolford (1984), the necessary and sufficient condition for the basis to be stationary is: $\rho_{1}<0, \rho_{2}<0$ and $\left(1+\rho_{1}\right)\left(1+\rho_{2}\right)<1$. 


\section{RESULTS OF THE ASYMMETRIC ERROR-CORRECTION MODEL}

Economically, money supply is the intermediate target of the Central Bank; therefore, changes in Bangladeshi money supply are induced by countercyclical monetary policy actions of the Bangladesh Bank. Thus, in the remainder of study, the phrase "countercyclical monetary policy action" is used instead of "change in money supply". The results of the cointegration tests used in the previous section necessitate the use of the TAR vector errorcorrection (VEC) model instead of the misspecified conventional VEC model. Therefore, an TAR-VEC model must be employed to further investigate the asymmetric dynamic behavior of the Bangladeshi money supply $M_{t}-$ induced by policy actions of the Bangladesh Bank and the real GDP, $y_{t}$, as well as the time lags of this causality. Additionally as aforementioned, the following TAR-VEC models differ from the conventional error-correction models by allowing asymmetric adjustments toward the long-run equilibrium.

$$
\begin{aligned}
& \Delta M_{t}=\alpha_{0}+\sum_{i=1}^{n} \alpha_{1} \Delta \partial M_{t-i}+\sum_{i=1}^{q} \gamma_{1} \Delta \partial y_{t-i}+I_{t} \rho_{1} \hat{\varepsilon}_{t-1}+\left(1-I_{t}\right) \rho_{2} \hat{\varepsilon}_{t-1}+u_{1 t} \\
& \Delta \partial y_{t}=\tilde{\alpha}_{0}+\sum_{i=1}^{n} \tilde{\alpha}_{1} \Delta \partial M_{t-i}+\sum_{i=1}^{q} \tilde{\gamma}_{1} \Delta \partial y_{t-i}+I_{t} \tilde{\rho}_{1} \hat{\varepsilon}_{t-1}+\left(1-I_{t}\right) \tilde{\rho}_{2} \hat{\varepsilon}_{t-1}+u_{2 t}
\end{aligned}
$$

where $u_{i, t} \sim$ i.i.d. $\left(0, \sigma^{2}\right), i=1,2$ and the Heaviside indicator function is set in accord with (5). This model specification recognizes the fact that the mutual responses between the countercyclical monetary policy action of the Bangladesh Bank and real GDP may be different, depending on whether the inflation is rising or declining.

As pointed out by Thompson (2006, pp. 327-328), the above specified TAR-VEC model differs from the conventional error-correction models by allowing asymmetric adjustments toward the long-run equilibrium. Also, the asymmetric error correctional model replaces the single symmetric error correction term with two error correction terms. Thus, in addition to estimating the long-run equilibrium relationship and asymmetric adjustment, the model also allows for tests of the short-run dynamic between the changes in the growth rate of the money supply and the changes in the real GDP growth rates. This in turn reveals the nature of their Granger causality.

In reporting the estimation results, the partial $F_{i j}$ represents the calculated partial F-statistics testing the null hypothesis that all coefficients $i j$ are equal to zero. " $* "$ and "***" indicate the 1 percent and 5 percent significant levels of 
both the F-statistics and the t-statistics. $Q_{L B}(2)$ is the Ljung-Box statistics and its significance is in square brackets, testing for the first two of the residual autocorrelations to be jointly equal to zero. $\ln L$ is the $\log$ likelihood. The overall F-statistic tests the overall fitness of the model. The retentions of estimated coefficients $\alpha_{i}, \gamma_{i}, \tilde{\alpha}_{i}$ and $\tilde{\gamma}_{i}$ are based on the 5 percent level of significance of the calculated $t$-statistics.

Table 2 reports the results of the asymmetric error correction model. A general diagnostic analysis of the overall empirical results indicates that the estimated equations (6) and (7) are devoid of serial correlation and have good predicting power as evidenced by the Ljung-Box statistics and the overall F-statistics, respectively. As to the short-run dynamic adjustment, the calculated partial statistics, partial $F_{12}$ and $F_{21}$ in equations (6) and (7), indicate unidirectional Granger causality from Bangladeshi real GDP growth rate to changes in money supply. This unidirectional Granger causality indicates that Bangladeshi real GDP is weakly exogenous from the countercyclical monetary policy actions by the Bangladeshi Central Bank. This weak exogeneity indicates Bangladeshi countercyclical monetary policy does not matter, at least in the short run. Additionally, this unidirectional causality flowing from real GDP to money supply can also be interpreted to mean that the Bangladesh Bank's utilization of countercyclical monetary policy tool to change the real GDP is in veil.

Table 2: Asymmetric Error Correction Model: TAR-VEC. Data, 1973:Q1 to 2009:Q4

\begin{tabular}{|c|c|c|c|c|}
\hline \multirow{3}{*}{$\begin{array}{l}\text { Eq. (6) } \\
\Delta \partial M_{t}\end{array}$} & \multicolumn{4}{|c|}{ Independent Variables } \\
\hline & \multirow{2}{*}{$\begin{array}{l}\text { overall } F_{(10,109)}=81 \cdot 1719 * \\
\alpha_{1}=\alpha_{2}=\alpha_{3}=\alpha_{19}=\alpha_{22}=0\end{array}$} & \multicolumn{3}{|c|}{$\ln L=-344.8103 Q(2)=1.6300[0.4415] ; \quad \bar{R}^{2}=0.8717$} \\
\hline & & $\gamma_{6}=\gamma_{9}=\gamma_{10}=0$ & $\rho_{1}$ & $\rho_{2}$ \\
\hline & Partial $F_{11^{-}}$stat. $=155.3634^{*}$ & Partial $F_{12}$-stat. $=8.4179^{*}$ & $0.5074^{* *}$ & 0.0938 \\
\hline \multirow{2}{*}{ Eq. (7) } & \multicolumn{4}{|c|}{ Independent Variables } \\
\hline & overall $F_{(9,135)}=40.1076^{*}$ & \multicolumn{2}{|c|}{$\ln L=-214.6223 Q(2)=0.4840[0.7850]$} & $=0.7669$ \\
\hline \multirow[t]{2}{*}{$\Delta \partial y_{t}$} & $\tilde{\alpha}_{1}=\tilde{\alpha}_{2}=0^{a}$ & $\tilde{\gamma}_{2}=\tilde{\gamma}_{3}=\tilde{\gamma}_{4}=\tilde{\gamma}_{6}=\tilde{\gamma}_{7}=\tilde{\gamma}_{12}=0$ & $\tilde{\rho}_{1}$ & $\tilde{\rho}_{2}$ \\
\hline & Partial $F_{21}$-stat. $=0.0556$ & Partial $F_{22}$-stat. $=48.5487^{*}$ & $-0.2999 *$ & -0.1487 \\
\hline
\end{tabular}

Notes: Partial F-statistics for lagged values of growth rates of money supply and real GDP respectively, are reported under the specified null hypotheses. $Q(2)$ is the Ljung-Box Q-statistics to test for serial correlation up to 2 lags. Overall F-statistics are for the respective overall equations. "** and "**" indicate 1 percent and 5 percent significance levels respectively.

a Even though only the first two lags are reported, the t-statistic indicates that the first 16 lags are insignificant at 5 percent level. 
Moreover, the calculated partial statistics, $F_{21}$ and $F_{22}$ in equations (6) and (7), suggest that the Bangladeshi monetary authority is very responsive to and tries to use countercyclical monetary policy instruments to manage the economy. The empirical results also suggest that the Central Bank considers the real GDP growth rates in the last ten quarters and the growth rate of money supply in the twenty two quarters in formulating its countercyclical monetary policy.

In addition to revealing the short-run dynamic Granger causality, the asymmetric error correction model also reveals the long-run behavior of the countercyclical monetary policy action of the Bangladesh Bank. The finding $\left|\rho_{1}\right|>\left|\rho_{2}\right|$ and only $\rho_{1}$ is significant at 1 percent level and $\rho_{2}$ is insignificant at any conventional level in equation (6) suggest that the Bangladesh Bank responds more quickly when inflation rate is above the long-run threshold then when it is below the long-run threshold. This empirical finding is consistent with the estimation results of the TAR model. With regard to the longrun adjustment of the real GDP, the estimation results for equation (7) also show that $\left|\tilde{\rho}_{1}\right|>\left|\tilde{\rho}_{2}\right|$; however, while $\tilde{\rho}_{1}$ is statistically significant at 1 percent level, $\tilde{\rho}_{2}$ is statistically insignificant at all conventional significant levels. These findings seem to indicate that the real GDP of Bangladesh responds to contractionary countercyclical monetary policy actions of the Bangladesh Bank only in the long run.

\section{EMPIRICAL FINDINGS AND POLICY IMPLICATIONS}

As to the behavior of the Bangladeshi inflation rates as defined by the quantity theory of money, the estimation results suggest that the inflation rate converges to its long-run threshold faster when it is above the threshold. Based on the empirical results from the estimations of equations (6) and (7), the finding that only $\rho_{1}$ in equation (6) and $\tilde{\rho}_{2}$ in equation (7) are statistically significant at any conventional level, coupled with the aforementioned negative sign preceding $\partial P_{t}$, suggests that Bangladesh Bank as well as the real GDP growth rate have been very responsive when the inflation rate is above its long term threshold in the long run.

With regard to the empirical results pertaining to the short-run dynamic causality, the calculated partial F-statistics from equations (6) and (7) reveal the unidirectional Granger causality from Bangladeshi real GDP growth rate to countercyclical monetary policy actions. This weak exogeneity indicates that the Bangladeshi monetary authority is very responsive to and tries to 
utilize countercyclical monetary policy instruments to manage the economy, but the monetary policy does not seem to matter in the short run.

Possibly, the most important contribution of this study to the literature, as disappointing as may be, is the empirically determination result that none of the $\tilde{\alpha}_{i} ; i=1,2, \ldots, 16$ in equation (7) is individually significant, based on the $t$ statistic, or collectively significant, based on the partial F-statistic, at 5 percent level of significance. This finding, coupled with the retentions of $\alpha_{1}, \alpha_{2}, \alpha_{3}$, $\alpha_{19}, \alpha_{22}$ and $\gamma_{6}, \gamma_{9}, \gamma_{10}$ in equation (6), indicates that the Bangladesh Bank has tried to use the monetary policy and considered the growth of money supply in the last twenty two quarters and the real GDP growth rate in the last ten quarters in formulating its policy to manage the macro economy. Unfortunately, its countercyclical policy has been totally ineffective in the short run. Consequently, the issue of Bangladeshi countercyclical monetary policy impact lag is irrelevant.

It has been well known that the root causes of the Bangladeshi banking sector problems, particularly the issue of the credibility of the central bank, are the lack of market economy disciplines and rampant political interference by the government over the operation of the Bangladesh Bank. Excessive government intervention and political connections, management corruptions, inefficiency and ineffectiveness are part of a vicious circle prevailing in the financial sector that tends to inhibit economic development, industrialization, and social progresses in poor and developing countries in general and in Bangladesh in particular. These problems cannot be corrected without the infrastructure of a more efficient and competitive financial sector and a more effective market economy. In this current environment, strong political will would be needed to reform the financial sector and thereby establish a more competitive and efficient banking sector that would be conducive to efficient financial management and thereby economic progress.

\section{CONCLUDING REMARKS}

This study estimated the threshold autoregressive (TAR) model developed by Enders and Siklos (2001) to examine the Bangladeshi inflation behavior, the Granger causality between countercyclical monetary policy as reflected in changes in money supply $M_{1}$ and output growth, as well as the time lags of this causality. The empirical results suggest that the Bangladeshi inflation converges to its long-run threshold faster when it is above the threshold than when it is below the threshold (please note that this interpretation reflected the negative sign preceding $\left.\partial P_{t}\right)$. 
As to the long-run policy implication of the empirical findings, the estimation results indicate either the Bangladeshi monetary authority has been more sensitive to GDP growth rate than inflation in the long run. As to the countercyclical monetary policy, the empirical findings indicate that the Bangladesh Bank has tried to utilize the monetary policy and considered the growth of money supply in the last twenty two quarters and the real GDP growth rate in the last ten quarters in formulating its policy to manage the macro economy. Unfortunately, its countercyclical policy has been totally ineffective in the short run. Consequently, the issue of Bangladeshi countercyclical monetary policy impact lag is irrelevant.

\section{References}

Ahmad S., 2012, “The Challenge of Controlling Inflation", 08 October, http:/ /www.pri-bd. org /index.php?option=com_content\&view $=$ article \&id=368: the-challenge-ofcontrolling-inflation\&catid $=47$ :bangladesh-economy\&Itemid $=59$

Arak M., S. Englander and E. Tang, 1983, "Credit Cycles and the Pricing of the Prime Rate", Federal Reserve Bank of New York Quarterly Review, Summer, pp. 12-18.

Chan K.S., 1993, "Consistency and Limiting Distribution of the Least Squares Estimator of a Threshold Autoregressive Model", Annals of Statistics, Vol. 21, No. 2, pp. 520-533.

Cook T. and T. Hahn, 1989, " The Effect of Changes in the Federal Funds Rate Target on Market Interest Rates in the 1970s", Journal of Monetary Economics, Vol. 24, pp. 331-351.

Daily Star, 2012, "Govt Borrowing is the Concern-Top Businesses Find Credit Growth of Private Sector at Stake", $9^{\text {th }}$ June.

Diebold F.X. and S.A. Sharpe, 1990, " Post-Deregulation Bank-Deposit-Rate Pricing: The Multivariate Dynamics", Journal of Business \& Economic Statistics, Vol. 8, No. 3, pp. 281-291.

Dueker M.J., 2000, "Are Prime Rate Changes Asymmetric?", Federal Reserve Bank of St. Louis Economic Review, September/October, pp. 33-40.

Enders W. and C.W.J. Granger, 1998, "Unit Root Tests and Asymmetric Adjustment with an Example Using the Term Structure of Interest Rates", Journal of Business and Economic Statistics, Vol. 16, No. 3, pp. 304-311.

Enders W. and C.W.J. Granger, 1987, “Cointegration and Error Correction: Representation, Estimation and Testing", Econometrica, Vol. 55, pp. 251-276.

Enders W. and P.L. Siklos, 2001, "Cointegration and Threshold Adjustment", Journal of Business \& Economic Statistics, Vol. 19, No. 2, pp. 304-311. 
Ewing B.T., S.M. Hammoudeh and M.A. Thompson, 2006, “Examining Asymmetric Behavior in U.S. Petroleum Futures and Spot Prices", Energy Journal, Vol. 27, No. 3, pp. 9-23.

Fisher I., 1911, The Purchasing Power of Money, New York: Macmillan, USA.

Forbes S.M. and L.S. Mayne, 1989, "A Friction Model of the Prime”, Journal of Banking and Finance, Vol. 13, pp. 127-135.

Friedman M., 1956, The Quantity Theory of Money - A Restatement in Studies in the Quantity Theory of Money, Milton Friedman, ed. Chicago: University of Chicago Press, pp. 1-21.

Frost D. and R. Bowden, 1999, "An Asymmetry Generator for Error-Correction Mechanisms, with Application to Bank Mortgage-Rate Dynamics", Journal of Business $\mathcal{E}$ Economic Statistics, Vol. 17, No. 2, pp. 253-263.

Goldberg M.A., 1984, "The Sensitivity of the Prime Rate to Money Market Conditions", Journal of Financial Research, Vol. 7, No. 4, pp. 269-280.

Hannan, T.H. and A.N. Berger, 1991, “The Rigidity of Prices: Evidence from the Banking Industry", American Economic Review, Vol. 81, No. 4, pp. 938-945.

Heffernan S.A., 1997, "Modeling British Interest Rate Adjustment: An Error Correction Approach", Economica, Vol. 64, pp. 211-231.

Hofmann B. and P. Mizen, 2004, "Interest Rate Pass-Through and Monetary Transmission: Evidence from Individual Financial Institutions' Retail Rates", Economica, Vol. 71, pp. 99-123.

Hubbard R.G. and A.P. O’Brien, 2010, Economics, Pearson/Prentice Hall, New Jersey, USA.

Khatun Fahmida, 2012, "State of Governance in the Banking Sector Dealing with the Recent Shocks", CPD Paper presented at the CPD Dialogue held on 05 November 2012 at BRAC Center Inn Auditorium, Dhaka, pp. 4-15.

Levine P. and P.D. Loeb, 1989, "Asymmetric Behavior of the Prime Rate of Interest", American Economist, Vol. 33, pp. 34-38.

Mester L.J. and A. Saunders, 1995, "When Does the Prime Rate Change?" Journal of Banking and Finance, Vol. 19, pp. 743-764.

Moazzami B., 1999, "Lending Rate Stickiness and Monetary Transmission Mechanism: The Case of Canada and the United States", Applied Financial Economics, Vol. 9, pp. 533-538.

Mujeri Mustafa K. and Islam Md. Ezazul, 2008, “Rationalizing Interest Rate Spread in the Banking Sector: Some Policy Suggestions", Policy Analysis Unit, Bangladesh Bank, Policy paper No. 0804. pp. 1-12.

Neumark D. and S. Sharpe, 1992, "Market Structure and the Nature of Price Rigidity: Evidence from the Market for Consumer Deposits", Quarterly Journal of Economics, Vol. 107, No. 2, pp. 657-680.

Nguyen C. and A. Islam, 2010, "Asymmetries in the Thai lending-deposit Rate Spread: An Econometric Analysis", Applied Economics Letters, Vol. 17, No. 13. pp. 1229-1236. 
Perron P., 1997, "Further Evidence on Breaking Trend Functions in Macroeconomic Variables", Journal of Econometrics, Vol. 80, pp. 355-385.

Petrucelli J. and S. Woolford, 1984, "A Threshold AR(1) Model", Journal of Applied Probability, Vol. 21, pp. 473-481

Sarno L. and D.L. Thornton, 2003, "The Dynamic Relationship Between the Federal Funds Rate and the Treasury Bill Rate: An Empirical Investigation", Journal of Banking and Finance, Vol. 27, pp. 1079-1110.

Scholnick B., 1999, "Interest Rate Asymmetries in Long-Term Loan and Deposit Markets", Journal of Financial Services Research, Vol. 16, pp. 5-26.

Sellon G.H., 2002, "The Changing U.S. Financial System: Some Implications for the Monetary Transmission Mechanism", Federal Reserve Bank of Kansas City Economic Review, First Quarter, pp. 5-35.

Thompson M.A., 2006, "Asymmetric Adjustment in the Prime Lending-Deposit Rate Spread", Review of Financial Economics, Vol. 15, No. 4, pp. 323-329.

Tkacz G., 2001, “Endogenous Thresholds and Tests of Asymmetry in U.S. Prime Rate Movements", Economic Letters, Vol. 73, pp. 207-211.

World Bank, 2012, http://data.worldbank.org/indicator/FR.INR.LNDP (accessed date: $30-12-12)$.

\section{Résumé}

Cette étude empirique démontre que l'inflation du Bangladesh passe à son seuil à long terme plus vite quand il est au-dessus du seuil déterminé de façon endogène de quand il est en dessous. En outre, les résultats des estimations révèlent la causalité unidirectionnel de Granger du taux de croissance du PIB réel à la politique monétaire anticyclique, c'est à dire, le taux de croissance du PIB réel est faiblement exogène des mesures de politique monétaire anticyclique du Bangladesh. Ces résultats indiquent que même si la Banque centrale du Bangladesh utilise sa politique monétaire pour gérer la macro-économie, l'argent et donc la politique monétaire ne semblent pas avoir d'importance à court terme. 
